\title{
Increasing the Adaptive Capacity in Unembanked Neighborhoods? An Exploration into Stakeholder Support for Adaptive Measures in Rotterdam, The Netherlands
}

\author{
Anita Kokx, Tejo Spit \\ Department of Human Geography and Planning, Faculty of Geosciences, Utrecht University, Utrecht, The Netherlands \\ Email: j.m.c.kokx@uu.nl
}

Received October 11, 2012; revised November 12, 2012; accepted November 19, 2012

\begin{abstract}
Cities in deltas are vulnerable to climate change, especially their unembanked neighborhoods that are not protected by dikes. Rising sea levels and extreme water levels in the rivers can lead to the flooding of these urban areas. The Netherlands has a long history in water management. However, building dikes and the elevation of land are traditionally treated as rather stand-alone measures. Attention is rarely paid to the surrounding area, let alone to the complex context of cities and certainly not to disadvantaged neighborhoods. Yet, inner-city area redevelopment may provide opportunities to integrate flood management in these planning processes. In order to investigate the support of stakeholders for risk-reducing adaptive measures and more resilient measures, we did research in an unembanked inner-city area in the city of Rotterdam (The Netherlands), in which we conducted in-depth interviews with the central stakeholders. The main conclusion is that the most important barriers for integrating climate adaptation measures into that neighborhood are the fragmentation of water-safety policy (e.g. elevation of rebuilding locations) and the hierarchical governance arrangement in water management. This type of fragmentation led on its turn to fragmentation with other policy goals for the neighborhood. It also led to fragmentation between different areas in the same neighborhood that received political attention and those that are excluded from water-safety policy. This questions the approach in terms of social justice. An important side effect is that this governance arrangement also restricted innovation towards climate adaptation. Therefore, integrating water-safety policies in urban planning (in its capacity as a more integrative and comprehensive spatial approach) should be considered the best option to increase the adaptive capacity in delta cities. Not only can the negative effects in terms of policy fragmentation be dealt with effectively, but also spatial fragmentation can be tackled.
\end{abstract}

Keywords: Adaptive Capacity; Inner-City Area Development; Unembanked Neighborhoods; Rotterdam; The Netherlands

\section{Introduction}

Cities in deltas are vulnerable to climate change. Dutch cities, as well as other cities in delta areas all over the world, are particularly vulnerable to flooding [1]. Rising sea levels and increasing rivers discharges can cause flood hazards from two directions: from the sea as well as from the rivers. Unembanked neighborhoods in delta cities are not protected by dikes. Therefore, they can become increasingly vulnerable to flooding in the future [2], while population growth and economic growth can increase flood damage and social disruption.

Climate adaptation is directed to reduce vulnerability to the impact of climate change [3]. Adaptive capacity is the capacity of a society to adapt and adjust to the uncer-

\footnotetext{
*This research project has been carried out within the framework of the Dutch National Research Program Knowledge for Climate

(www.knowledgeforclimate.org). This research program is co-financed by the Ministry of Infrastructure and the Environment.
}

tain effects of climate change. It depends on geographical location, knowledge, and institutional, political, financial and social factors [4]. How the adaptive capacity with respect to flooding can be increased in unembanked inner-city neighborhoods is the central focus of this paper. Water management is the traditional instrument to prevent flooding, at least in The Netherlands. The country has a long history in water management. However, water management (hydraulic engineering) was less and less integrated with other policy fields, such as with urban planning, and did not pay much attention to the surrounding area [5], let alone to the complex context in cities and certainly not to disadvantaged neighborhoods.

On the other hand, waterfront developments on former (unembanked) docklands and the urban restructuring of disadvantaged neighborhoods are now considered to be important for improving the image, economic prosperity and housing in Western delta cities [6,7]. Furthermore, 
the concept of resilient cities has come to the fore, emphasizing the functioning of the city as a social-ecological system (see for an overview e.g. [8]). Along with environmental resilience, such as with respect to climate change, social resilience would also be required to cope with external stresses and disturbances caused by social, economic, political and environmental change [9].

Therefore, integrating climate adaptation in spatial urban planning would be the new urban challenge (see e.g. [6,10-12]), because urban planning exercises a more longterm perspective with respect to social-economic and environmental developments, which equals the long-term horizon in climate change.

Yet, inner-city area redevelopment may provide opportunities to integrate flood management in these planning processes. In doing so, the adaptive capacity to cope with the effects of climate change might increase. Therefore, it is important to investigate the stakeholders' perceived barriers to and opportunities for integrating climate adaption in inner-city area development, so that lessons can be learned for other urban areas. The aim of this paper is to shed some light on this. We used the Feijenoord-Noord neighborhood in the city of Rotterdam (The Netherlands) as our case study to elicit the information. This type of neighborhood can be found all over the world in delta areas, ranging from Bangkok to New Orleans and we presume that the Dutch experiences can easily be translated into their context. The central research question to address is: Which factors contribute to or constrain support for acceptation and implementation of effective adaptation measures in Feijenoord-Noord by different types of actors, and what lessons can be learned for other urban development processes?

In order to investigate the support of stakeholders for risk-reducing adaptive measures and more resilient measures (see below), we conducted in-depth interviews with the central stakeholders. We interviewed public officials of the municipality of Rotterdam and the Feijenoord Borough, managers of real-estate development companies, a housing association, a large company, and active residents in the neighborhood. Each interview was recorded and transcribed in full.

We used network-governance theory and the theory of governance of climate adaptation as our theoretical framework. These are discussed in the next section. This offers assumptions on the critical factors that would increase the adaptive capacity in cities. In Section 3 we give information about the urban restructuring neighborhood Feijenoord-Noord in the city of Rotterdam and Dutch water-safety policies. Because actor satisfaction with the policies is related to actor satisfaction with the policy process $[13,14]$, we investigated both aspects of climate adaptation governance. In Section 4 we report our findings about stakeholder satisfaction with the process and governance arrangement. We investigate stakeholder sup- port for climate adaptation measures with respect to water-safety in Section 5. We conclude this paper with our major findings in Section 6. These will contribute to the broader international debate about effective climate adaptation governance.

\section{Urban Governance and the Governance of Climate Adaptation}

Without doubt, a successful response to climate change in cities, or in other words adaptive capacity, would need cooperation between a broad range of actors: urban governance. Urban governance can be defined as "the process of steering and coordinating urban policies between the public, private, and voluntary sectors to achieve collectively-agreed goals" [15]. According to various authors (see e.g. $[16,17])$ stand-alone or sectoral solutions are insufficient for effective climate adaptation because climate change influences many social fields and effective climate adaptation also depends on it to increase the adaptive capacity. Government, the market, social networks and citizens' social capital would be equally important to increase this capacity [18].

Integrated policies are also important for the sustainable development of society and of European cities, such as in disadvantaged neighborhoods [19]. However, policies for complex problems are often made in different policy networks (arenas) simultaneously. This could lead to fragmented policies, such as for urban restructuring neighborhoods [7]. One of the most important barriers to climate adaptation in Western cities is policy fragmentation due to a sectoral focus on climate adaptation in local government $[20,21]$. Instead of the narrow focus on regulation in water management, strategic integral spatial planning can fulfill an important role in policy integration [22], because of its ambition to integrate all types of policy with spatial effects. However, up to now climate adaptation is not structurally embedded in Dutch urban planning [23]. Therefore, this would be a big challenge, for example in inner-city area development.

Furthermore, stakeholder support for climate adaptation is extremely important in the implementation of (new) climate adaptation policies. This will increase the legitimacy of the policies (equity and acceptance) [2426]. Acceptance is the individual evaluation of a policy process and the content of the policy, while support is the aggregate of acceptance [14]. Therefore, we measured the support through a multi-actor evaluation of the process and policies [27]. In addition, it would be easier to gain support for flexible climate adaptation measures that can be adapted latter, than for measures that are ireversible [28]. Stakeholder support can also prevent policymakers choosing climate adaptation options that cannot be implemented reasonably by stakeholders [24]. 


\subsection{Adaptive Governance}

Moreover, in governance processes resources (money, knowledge, information) can be shared between stakeholders [29]. This might also increase the adaptive capacity $[17,30,31]$. Interactive iterative processes might lead to a shared vision on the policy problem and the best policy solution [29]. This might also lead to policy innovation [13], such as for climate adaptation [26,32,33]: adaptive governance. This implies that the policies should be flexible, so that new insights and circumstances can be taken into account and new actors can be involved [34]. Therefore, climate adaptation decision making must also be a flexible and dynamic process, in order to take uncertain climate change into account and to increase the adaptive capacity effectively [17,35-39].

However, Dutch urban restructuring practice-its inflexibility, reflected in risk-avoiding behavior-is paramount. It restricts policy innovation [7]. This can also be the case in our case study. Also, a lack of a sense of urgency to adapt to climate change can affect the adaptive capacity negatively, owing to a lack of social support [40] and lack of political will [41]. However, policy entrepreneurs can generate policy change, especially by using "windows of opportunity" and their professional networks effectively $[42,43]$, such as for climate adaptation [44].

Klijn and Koppenjan [45, p. 19] define policy networks in public governance as "a (more or less) stable pattern of social relations between interdependent actors, which take shape around policy problems and/or policy programmes.” Adaptive policy networks are sensitive and adaptive to their (policy) environment and can generate policy change. However, policy networks that are very closed are more or less insensitive to the multiple contexts around them and are not open to policy change [34].

We might expect an adaptive policy network in our case study, because this would deliver integrated policies (including water safety), and a sustainable joint-working capacity by sharing responsibilities and resources between local government, real-estate development companies, the housing associations and residents.

\subsection{The Governance Arrangement}

The promises of normative network theory (inclusion, better policies and easier implementation by sharing resources: [29]) are not always fulfilled in practice, owing to conflicting pressures from networked, hierarchical and market forms of governance $[7,46]$. The institutional design or governance arrangement (the inclusion/exclusion of actors; their degree of influence and the roles and tasks the actors have to fulfill) structures the cooperation process [47]. Therefore, the governance arrangement is extremely important for the actors' satisfaction with the policy process and the policy content. The more they are satisfied with the process, the more they are satisfied with the policy content $[13,14]$. However, diverging perceptions or different frames of reference (ambiguity: [48]) regarding the roles and tasks between the public and private domains and the content of the policies can impair effective cooperation. Consequently, consensus among stakeholders about climate adaptation is not self-evident, owing to diverse values, beliefs, understandings, norms, policy cultures and so on [11].

Traditional hierarchical steering, for example, can hinder horizontal cooperation, because insufficient attention can be paid to the specific local context and actors' interests $[7,46,49]$. In sharp contrast to hierarchical uniform regulation, climate adaptation should be a very context-specific process, with specific context-dependent climate adaptation options $[16,36]$. Furthermore, under neoliberalism, government can transfer the public costs of the policies to the market and their citizens. This can lead to boundary disputes between the public and private domains [50]. Consequently, disagreements about responsibilities decrease the capacity for cooperation in urban restructuring [7]. This can also be the case in our case study with respect to climate adaptation.

In addition, involving the community in policy formation might develop social capital and community cohesion, improve service delivery and meet local needs [51], such as in climate adaptation [52]. However, in practice residents often have a marginal role in strategic decision making for their neighborhood [7,51] and in climate adaptation policies [21]. Therefore, the policies are often directed to meet the particular interests of the organizations involved, and not those of the residents [53]. Furthermore, the manner in which climate adaptation is implemented directly questions the social justice in how the risks are divided in communities [18].

To summarize, the general barriers to integrating climate adaptation in urban planning can be found in such factors as policy fragmentation, the lack of a sense of urgency, hierarchical steering, different frames of reference and the exclusion of residents.

\subsection{Barriers for Climate Adaptation in Cities}

In addition to these more general barriers, climate adaptation in cities is not easy to achieve. For example, existing spatial functions cannot be easily restricted or displaced [30]. Fragmented ownership and management of land and housing can also restrict opportunities for adaptation [54]. In addition, many adaptation measures require more land in public space or a less compact built environment [55]. Climate adaptation in cities can also be very expensive. Therefore climate adaptation can often be implemented over a long time horizon, because 
buildings and infrastructure have a very long lifetime [56]. Moreover, the effects of climate change differ between neighborhoods and depend, for example, on the density of the built environment, the amount of green and water storage, and the quality of the existing sewer system. Furthermore, economic values (profit, employment) often have more weight than softer values, such as the quality of the living environment in urban neighborhoods and benefits for the long term. This makes it extremely difficult to combine long-term goals, such as climateproof neighborhoods, with short-term goals [57].

All these barriers reveal that the opportunity to adapt to climate change is highly context specific, because it depends on the climatic, environmental, social and political conditions in a specific location [17]. However, according to Adger and colleagues [11] most perceived limits to adaptation are social constructions (e.g. ethics, knowledge, attitudes to risk, policy culture). These socially constructed limits may also be mutable. In particular, urban governance and planning practices can meaningfully challenge the perceived technical, social and institutional barriers of adaptation among stakeholders by reframing perceptions (see e.g. $[12,58])$, in order to achieve climate-proof urban areas.

\subsection{Strategies for Climate Adaptation in Urban Planning}

A strategy to achieve the support of various interdependent actors is joint image-building by creating a common ground that enables the mutual adjustment of strategies and joint action (see [58]). Furthering goal intertwinement is one of the strategies to achieve this joint action. The aim of goal intertwinement is that solutions are developed and selected that satisfy all actors involved, because all will perceive an improvement with respect to the existing or expected situation.

The essence of goal intertwinement is the acceptance of differences. This can accommodate diverging or conflicting objectives. Intertwinement might bind actors together and create opportunities to share cost. Through the linking of different policy networks and goals, new opportunities can emerge. Goal intertwinement can take place along various lines [58]. For example, through an integrated design the scope of a problem definition (e.g. integrated area development instead of only climate change) can be enlarged. Scope enlargement may give more room for goal intertwinement and sharing of resources, because more actors are involved. Climate-proof components in public space also create much public and private value or benefit (see e.g. [59,60]).

Furthermore, climate adaptation measures can easily be attached to maintenance or replacement investments. Thus, goal intertwinement (as a window of opportunity) is a cost-effective strategy to link climate adaptation to other policy aims and investment agendas. In addition, no-regret measures can prevent no climate adaptation taking place at all. Willows and Connell [61, p. 66] define no-regret options as options (or measures) that can be justified under all plausible future climate change scenarios, including the absence of human-induced climate change. Thus, a no-regret adaptation strategy limits the impact of climate change and delivers benefits in economic, social or environmental terms even in absence of climate change.

In the research, we investigated stakeholders' perceptions about the effective use of these strategies in our case study.

\subsection{Climate Adaptation Measures for Unembanked Neighborhoods}

To adapt to climate change in unembanked urban areas, there are two broad strategies: first, by increasing the resistance against flooding, such as by elevating the landthis fits within the traditional top-down paradigm in Dutch water management, based on models to reduce uncertainty, the calculation of statistical risks, and taking preventive measures; second, by increasing the resilience so that the consequences of flooding are restricted and the areas can recover quickly - this is a more bottom-up approach, wherein uncertainty about the effects of climate change is accepted and learning from the past is emphasized (adaptive management) [62].

There are several measures that can increase this resilience, such as increasing the self-reliance of residents through good communication; evacuation routes; the creation of refuge areas; construction measures that restrict the damage to buildings, electricity and communication networks; adaptive roads, so that water can be transported quickly towards outside the area; insurances against flooding; and a non-hierarchical management structure with short communication lines (flexibility) [62-64]. Thus, this approach is based on recovery and flood resilience measures. System robustness (e.g. an unbanked area as a flood risk system) is featured by both response and recovery, whereas vulnerability is the flip side of system robustness [35].

A variety of preventive and resilience measures can increase the adaptive capacity of an area, because it can better cope with the uncertainty of climate change [39]. We investigated the stakeholder support for both riskreducing and resilient adaptive measures (see Section 5).

To summarize, the critical success factors for the governance of climate adaptation are adaptive policy networks, integrative policies, learning and experimentation, flexibility, stakeholder support, goal intertwinement, and the effective use of windows of opportunity. 


\section{Feijenoord-Noord in the City of Rotterdam and Water-Safety Policies}

\subsection{The Case Study}

The city of Rotterdam is located at the edge of the southwest delta area of The Netherlands, with the North Sea to the west. The Nieuwe Maas River separates the city into a northern and southern part (see Figure 1).

Until the nineteenth century, the city of Rotterdam was built on the north bank of the river, and was mainly protected by dikes. A new deep-water channel, the "Nieuwe Waterweg", improved access to the port of Rotterdam, and exaggerated urban development on the south bank during the nineteenth and twentieth centuries, including harbors, infrastructure and housing. Part of these developments took place in unembanked areas, directly adjacent to the river [2], such as in our case study of the Feijenoord-Noord neighborhood

In this neighborhood, urban restructuring of the housing stock (renovation/demolition/new housing) took place

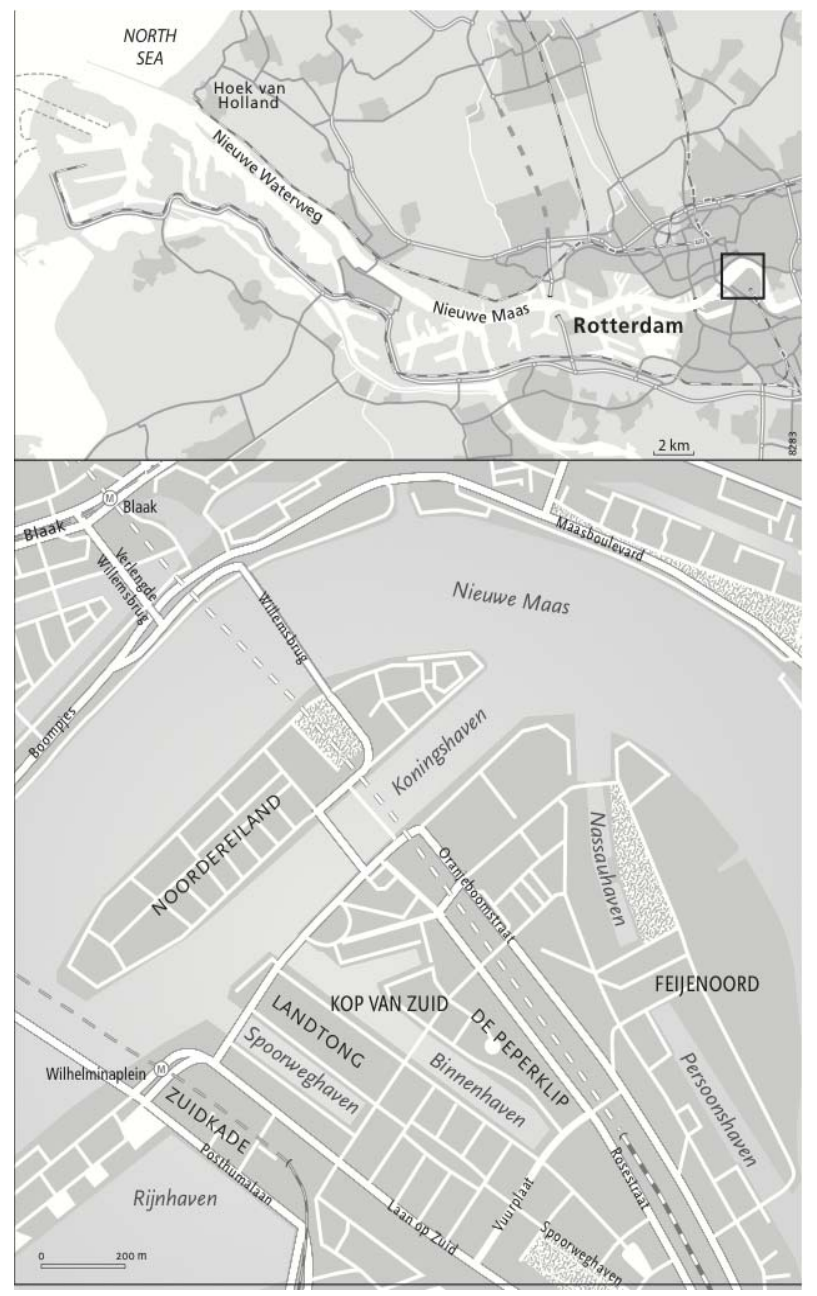

Figure 1. The location of Feijenoord-Noord in Rotterdam, The Netherlands. during the 1970s, and some companies have been displaced. Some 7300 people live in the Feijenoord neighborhood, and it accommodates many young people (33\% $<20$ years). The ethnic minority population is relatively large. Residents' income is relatively low compared with the city and the national averages. Poverty is one of the main problems in the area, as well as social safety and criminality [65].

In the Masterplan for the area, "Kop van Feijenoord" [65], one of the most important aims is improving the living environment for the current residents, as well as creating new residential milieus for new residents (middle- and upper-income groups). Also, public space will be improved with quays, parks and squares.

\subsection{Water-Safety Policies}

Dutch water-safety policy is based on so-called morelayer safety, namely prevention as primary pillar; sustainable spatial planning (pro-action); disaster management (response). Local government is responsible for water safety in Dutch umembanked areas. In addition, end users are responsible for flood resilience measures and the risk of floodwater damage in these areas [66,67]. To prevent flooding from the sea, the Measlandt Storm Surge Barrier has been built in the north of the Nieuwe Maas. It closes when the sea level is expected to rise by more than +3 meters Normaal Amsterdams Peil [NAP]. A NAP of 0 is the average sea level of the North Sea.

Over the course of time, the south bank of the Feijenoord-Noord area has been elevated from +2.5 NAP to +3.90 NAP. The Noordereiland, the isle in the river, is the lowest part of the area (+2.25 NAP). Current vulnerability for frequent flooding is relative low, but it is vulnerable to extreme situations. In the future, climate change may increase this vulnerability by raising sea levels and increasing rivers discharges. Further urbanization also increases this vulnerability $[2,64,68]$. The Masterplan "Kop van Feijenoord" advises the elevation of new buildings blocks towards +4.10 NAP [65]. The masterplan's advice will be followed unless a risk analysis says otherwise [68].

\section{Perceptions about the Governance Arrangement}

In the interviews stakeholders are asked about their perceptions regarding the division of responsibilities between government and the market with respect to the water safety in the area.

All stakeholders perceive a shared responsibility with respect to the inner-city area development and the implementation of climate adaptive measures. However, there is no total financial strategy to implement the masterplan, owing to a negative land-exploitation budget. Therefore, the scope of area development is reduced (divided into 
sub-plans). This implies that the costs cannot be shared within the whole area development but must be negotiated repeatedly, whereas scope enlargement gives better opportunities for sharing costs [58].

With respect to water-safety policies, the stakeholders stress that local government sets the standards, and realestate developers are obliged to adhere to this standard. This implies that local government exercises its responsibility through traditional hierarchical steering by regulation, namely by setting standards with respect to the ground level for rebuilding locations. However, realestate developers and the housing association involved are dissatisfied with this top-down steering, because they have to pay all the costs of adaptation, as this real-estate developer illustrates:

Owing to the financial crisis, the cheapest solution for the municipality at this moment is to elevate the ground level towards 4 meters. They put the financial burden onto the developer.

Thus, in his opinion local government passes the costs onto the development companies (see also [50]). Also, the hierarchical steering does not give any incentive to develop alternative adaptive measures. A respondent from a housing association expresses this as follows:

We keep it in mind (water safety), but not otherwise than is prescribed by the municipality, and that is the standard ground level.

According to a public official, more freedom and responsibility for real-estate developers would lead to more innovative solutions than local government would offer. Also, a real-estate developer emphasizes the importance of being innovative. In his opinion, adaptive construction can be used as a marketing instrument, and innovation would also be important for the survival of the company:

We can use it as marketing, because we show that we are a progressive company: that we want to go further than just stacking bricks. Ultimately, we have to innovate. Otherwise, we stand still and go backwards.

However, this real-estate developer also emphasizes that the traditional measure of elevating the land restricts the company in being innovative. Thus, whereas the market has a self-steering capacity to be innovative, hierarchical steering with only one adaptive instrument (elevation of the land in rebuilding locations) restricts innovation in climate adaptation. An explanation for this onesidedness and inflexibility can be found in the path-dependency of former water-safety policies, such as a realestate developer stresses:

I notice that Feijenoord is not a very experimental area for the municipality. Many things cause this. The plan just runs for a long time. A few years ago this was of no importance.

Recently, local government has set the first steps in adaptive management $[26,28]$ (bringing stakeholders together, information and communication). Public profes- sionals and representatives of the market are brought together in expert meetings. This illustrates the dynamic in these processes [36]. The professionals interviewed are satisfied with these meetings. However, more steps should be made:

This process is then started. I also participated in sort of strategy session to talk about this: "If we do it, how we do it?” That's all passed in review, and I then also said: "It's fine to talk about it, but when will something happen?” We need each other, so in that sense it is good to recognize solutions and to respect each other's interests.

Thus, it is important to take each other's interests into account (equity: [24]).

Furthermore, a public official stresses that cooperation with market parties would offer local government more substantive and strategic certainty about the implementation of the policies (see also [58]):

If you involve these professionals then you know that they really want to do this. Or if government prescribes some (unacceptable) requirements, are we then going to stop all developments? Especially nowadays, it is important to take this into account.

However, until now the residents of Feijenoord-Noord have been excluded from these meetings, while they are the target group [53] of water-safety policies for their neighborhood.

To summarize, local government and the market are mutually dependent and perceive a shared responsibility for climate adaptation. However, market parties are dissatisfied with the hierarchical steering in this neo-liberal governance arrangement, because only they pay the costs of water safety in the neighborhood. From a market perspective (maximize profit through reduction of costs and innovation), their opinion is understandable. However, the path-dependency of local government in the former hierarchical steering of water management influences the choices that have been made until now. From a traditional government perspective (legal certainty and equality of rights), this steering is also understandable. This clearly illustrates the ambiguity in perceptions about the division of responsibilities between government and the market [48].

Besides, this governance arrangement and the use of only one steering instrument restrict innovation in climate adaptation, because experimentation and learning have no chance to come to the fore. This can restrict adaptive capacity in the future $[26,32,33]$. Owing to the exclusion of residents in the interactive meetings, it is not clear which role they can fulfill to increase the adaptive capacity.

\section{Stakeholder Support for Adaptive Measures to Improve Water Safety}

Also, stakeholder support for the policy content is extremely important to increase the legitimacy and imple- 
mentation of policies [24,25]. Furthermore, a variety of preventive and resilience measures increases the adaptive capacity, because it can better cope with the uncertainty of climate change [39]. In this Section we investigate stakeholder support for various adaptive measures, based on the stakeholders' most mentioned measures during the first expert meeting. But first, we explore the sense of urgency and perceived risks in this case study, because these can influence perceptions about the necessity to take adaptive measures [41].

\subsection{Urgency and Risks}

All stakeholders perceive a greater sense of urgency for the Noordereiland (the island in the Nieuwe Maas River) than for the area on the south bank, because the quays of the Noordereiland are already prone to flooding:

You need a provision for the Noordereiland, because now the parking lots are sometimes flooded, but in 10 years it will come to the houses.

According to the stakeholders, the historic value of the buildings makes the island extra vulnerable to climate change. Besides, no urban restructuring of the dwellings is foreseen. This implies that adaptive measures can be taken mainly in public spaces. In strong contrast to the Noordereiland, for the area on the south bank stakeholders refer to the low and unclear probability of flooding in relation to the equity of the costs of adaptation. This affects the willingness to invest, as a respondent from a large company illustrates:

When the danger is very realistic, of course then there will be money for it. But for this type of scenario it is often difficult to be really able to demonstrate that it will happen in three years... We have the willingness to invest, but not when it is quite vague. Anyway, this is it at this moment.

Furthermore, various flooding scenarios lead to different risk models. According to the stakeholders, this also restricts a good assessment, and these models cannot guarantee water safety. A strong focus by government on risk management could even lead to a false sense of safety, as a public official stresses:

I think we go too far in the avoidance of all risks. In my view we create a false sense of safety by thinking we arrange this, we arrange that, so now we run no risk. But it does not work it this way!

This implies also that resilient adaptive measures would be needed in the event of an emergency [39].

To summarize, stakeholders perceive a greater sense of urgency for the Noordereiland than for the area on the south bank of the river. Important factors in the (un)willingness to invest are experiences with current flooding [41]; uncertainty about the exact risks of flooding; the equity of the costs in relation [24] to a vague acceptable risk; and the restrictions of statistical models.

\subsection{The Elevation of Land (Preventive Measure)}

Real-estate developers mention that, in comparison to another unembanked inner-city area development in Rotterdam, the cost of elevation of land is not the most important barrier here. This indicates that the financial acceptance of this measure is very context dependent. Besides, the housing association mentions that this adaptive measure requires no further adaptive measures in the construction of new dwellings, and is therefore from a technical and financial point of view relatively easy to implement.

However, all stakeholders are of the opinion that this measure causes very negative effects on spatial quality owing to different ground levels between the rebuilding locations and the surrounding areas, which causes problems with urban design. Besides, further uncertain climate change is not taken into account, as a real-estate developer stresses:

A disadvantage of a floor level of 4 meters is if suddenly in about 40 years it turns out that 4 meters is no longer safe... That is pretty difficult, you're no longer safe and can do nothing anymore.

In addition, all stakeholders mention that this measure to increase water safety in the neighborhood is not an integral solution, because only rebuilding locations will be evaluated. Thus, this leads to fragmentation between different areas in the same neighborhood: those that receive political attention and those that are excluded from water-safety policy. For the current residents, this would not be an acceptable solution:

Of course, that is not desirable. Basically, you want everyone to have dry feet. Ideally, you want everyone to be safe and nobody to be flooded.

Furthermore, according to the housing association, it can decrease the support for more expensive new housing in the neighborhood. In its turn, this can affect social cohesion between residents in the new dwellings and those in the existing housing stock owing to a "we versus they" way of thinking (see e.g. [69]), whereas one of the main objectives of the area development is the improvement of the quality of the living environment for the current residents [65]. A public official summarizes stakeholder dissatisfaction in the following way:

By both the Urban Design Department (municipality) and the developing parties this is perceived as not so good option for spatial quality. Both, we don't think much of it. In addition, we find it actually rather divisive that you organize it properly for the new residents and not for the current residents. Elevation of the land in existing urban areas is really especially difficult, because the quality is not improved for the current residents.

However, despite all these disadvantages, until now real-estate developers have chosen this adaptive measure for a rebuilding location, in order to minimize financial, 
technical and market risks.

To summarize, this adaptive measure reduces financial and construction risks, whereas support from a physical and social point of view is very restricted because it leads to poorer spatial quality, a spatial division in water safety, and to possible negative effects on social cohesion. Therefore, it is not an integral $[16,17]$ but a sectoral approach, which only emphasizes the water safety of rebuilding locations. There is no goal intertwinement [58] with other policy aims. Furthermore, it is an inflexible measure with respect to further uncertain climate change, while many authors stress the importance of flexibility $[17,36-39,62]$.

\subsection{Quay, Dike and Retaining Wall (Preventive Measures)}

Stakeholders perceive the elevation of the current quay as an expensive measure for the Noordereiland, whereas a retaining wall on the quay, combined with a bench, would be a better option here because it would also contribute to spatial quality. On the south bank of the area, elevation of the quay is only acceptable when is it combined with a boulevard (waterfront) so that it also contributes to the improvement of the spatial quality of the area, which is one of the aims of this inner-city area development [65]. Thus, goal intertwinement [58] contributes to the support for climate adaptive measures. In contrast to the elevation of the land just of the rebuilding locations, it would contribute to the water safety of the whole neighborhood. It also does not require adaptive measures in the existing housing stock:

Then you are at once rid of the problem and it contributes to the quality of the area. It has fewer consequences for the individual dwellings, because this solution is more an integral solution, which also protects the existing housing stock.

Furthermore, there is no support for the construction of a dike around the area, because it requires too much space [55] and costs too much money since many dwellings would have to be demolished.

\subsection{Dry-Proof Construction (Preventive Measure)}

In dry-proof buildings the external walls are used to hold back the floodwater (water resistant). According to the stakeholders, dry-proof dwellings require many technical construction measures, whereas there is currently no Dutch construction regulation for this type of buildings. Besides, other adaptive measures in public space would be also required in this case study (temporary retaining walls). Furthermore, the financial feasibility of dry-proof construction is related to the potential flood depth in flood-prone areas. This adaptive measure would be too expensive in this case study:
Then, the costs are so terribly high, because you must make many arrangements, like a kind of shell all the way around, and all streets must be prepared to be closed for the potential event of flooding.

However, there would be fewer financial disadvantages for apartment blocks. Thus, support depends also of the housing type. According to one real-estate developer, the feasibility of dry-proof construction is also restricted by former decisions on the elevation of the land, whereas in his opinion it should be a condition for urban design from the start.

To summarize, except in the case of apartments blocks, there is not much support for dry-proof construction. Factors that contribute to this lack of support are the costs in relation to the potential high depth of flooding in this case study, the lack of specific construction regulation, and former decisions about climate adaptation that block innovation in the case of for dry-proof construction.

\subsection{Wet-Proof Construction (Resilient Measure)}

Wet-proof construction implies that the shield and materials inside the building are water resistant, so floodwater damage can be quickly restored. After cleaning, it can quickly be put into use again. However, according to the real-estate developers, because of the potential high depth of floodwater in the area many measures should be taken in the dwellings. They also question the social acceptance of much floodwater in the dwellings:

What, you must accept a meter of flooding water in the dwelling? What do you have to do to meet all those requirements? Saying that with wet-proof construction it may be wet, and the water may be standing a meter deep in your living room. That seems to us not appropriate for a residential function. You can't do that to people!

Therefore, there is not much stakeholder support for this measure in the case study. According to a real-estate developer, adapting the occupancy of the dwelling by displacing the residential function to a higher floor would be a good solution from a technical and urban design point of view. However, the housing association does not accept this for the existing housing stock, because it leads to vacancy and consequently has negative effects on the housing exploitation budget. They also mention, just as residents do, that it has negative effects on livability (social safety), because social control on the streets will disappear. According to the housing association, displacement to a higher floor level in new dwellings is also more expensive than traditional construction, because it requires extra construction measures. Furthermore, it leads to spatial functional restrictions, whereas residents stress that many (older and immobile) residents prefer to live on the ground floor with a garden. 
To summarize, just as with dry-proof construction, the feasibility of wet-proof buildings depends on the potential flood depth in the area, the required construction measures, the social consequences and the housing type. For apartment blocks, there is more support. There is no support for displacement of the residential function to a higher floor level in the existing housing stock, because of its negative effects on the housing exploitation budget and on the livability in the area, owing to the disappearance of social control.

\subsection{Small Preventive Spatial and Construction Measures}

Adaptive measures can also contribute to water safety in public space, for example by redesigning the street, and squares and parks for extra water storage (resilient measures). A public official stresses that adaptive measures in public space can be easily linked with other measures in public space and investments:

If the entire street must be opened for a new sewer, then make the sewer pipes slightly larger, so more water can be discharged. Pay attention to the design of the green area, or to the sidewalks or roads, so not all the water flows into the sewer drains, but the rain can reach the groundwater and so can flow away more slowly. Of course, you can easily take that kind of measures anywhere. I think it does not cost extra money.

Thus, these windows of opportunity [42] are an efficient manner of linking climate adaptation with other policy aims in the neighborhood by seeking goal intertwinement [58]. Over and above that, they are also no-regret measures, because they always contribute to other aims rather than only to water safety [61]. According to the stakeholders, the use of traditional water-resistant floodwalls (resilient measure) that can be placed before windows and doors in the event of high water also contributes to water safety. In the opinion of the housing association, this would be a better measure than elevation:

I think it is better to make water-resistant floodwalls before the doors or a door with two hatches. That seems to me better than elevating the whole dwelling.

According to the stakeholders, high ventilation registers (preventive measure) for the protection of vulnerable elements in public space, for example in electricity transformer stations, also contribute to water safety and prevent social disruption.

To summarize, in public space and buildings it is easier to gain support for small flexible measures than for measures that are irreversible [28], such as the elevation of land. Over and above that, climate adaptation can be implemented step by step in integrated area development by linking it to other investments [24].

\subsection{Risk Communication, Evacuation Routes, and Elevation of Infrastructure (Resilience and Preventive Measures)}

Risk communication (resilience measure) increases the self-reliance of residents [39]. However, until now local government and the housing association did not pay any attention to informing residents about the risks of flooding and the measures they could take. Also, the residents interviewed have no idea in which direction they have to flee in the event of an emergency.

According to public officials and the housing association, residents have no sense of urgency with respect to water safety, owing to their many daily personal concerns. Most likely, this implies a low self-reliance capacity among the current residents, which makes them extra vulnerable. This also emphasizes the importance of good risk communication. However, none of the stakeholders links the policy aim of increasing the (economic) selfreliance capacity of residents in the area with increasing their self-reliance capacity to climate change. Thus, goal intertwinement with social policy aims has not taken place. Besides, no link has been made with increasing the social capital (social networks and social support) to increase the adaptive capacity in the event of an emergency [18,70]. However, according an older resident with experiences of the flood disaster in the area in 1953, the importance of social capital comes prominently to the fore, namely in giving shelter to those whose dwellings were flooded:

In that little house we have been together with 14 other people, because their house was wet. My parents said: "Come upstairs, we put some mattresses on the floor."

Stakeholders underline the importance of good risk communication and evacuation routes, such as on elevated (tram) roads. However, there is much uncertainty about how good risk communication should be handled, for example, to which target groups it should be directed and how they should communicate about statistical flooding risks. This implies that professional risk communication is necessary to increase the adaptive capacity of residents.

\subsection{Insurance (Resilient Measure) and Spatial Zoning (Preventive Measure)}

Insurance is an adaptive measure to increase recovery capacity after a flood. Nevertheless, in The Netherlands insurance against flooding is still not available. Stakeholders perceive insurance as an interesting option in relation to the acceptance of risks and the costs of adaptation. But, according to a real-estate developer, Dutch insurance companies should always require adaptive measures to prevent floodwater damage, such as dry-proof and wet-proof construction: 
They want to ensure if we design something it is wetproof or dry-proof, in which the damage is acceptable. So, when we have developed it wet-proof and the floodwater comes higher, then it is insured. But if we build houses at the current ground level and we say it can be flooded, the insurers say: "We don't insure that."

This implies that insurance is not a structural adaptive measure, because other adaptive measures should always be taken.

Preventing location of vulnerable spatial functions in the area (kindergartens, schools, nursing homes) by means of zoning plans can prevent flood victims. However, none of the stakeholders perceive this as a realistic option, owing to the desirability of these functions for the livability in the neighborhood.

To summarize, we conclude that support in several dimensions (financial, spatial, technical, social) of some adaptive measures (elevation of land, quay, dry-proof and wet-proof construction) is very context specific. It depends on the situation of the spatial design, decisions about the housing stock, and the potential flood depth. This implies that in another context support could be rather different. Therefore, there cannot be a blueprint for climate adaptation (see also: [16,36]), but rather it requires an integral adaptive strategy (costs, (external) effects), such as is stressed by many of the stakeholders interviewed, in order to increase broad stakeholder support (equity and acceptance of the policies: see e.g. [24-26]).

\section{Conclusions}

The focus of this paper has been on identifying the factors that contribute or constrain support for acceptation and implementation of effective adaptation measures in delta cities. We conducted in-depth interviews with professionals from local government, real-estate development companies and housing associations, and with active residents in the unembanked Feijenoord-Noord neighborhood in the city of Rotterdam. Because actor satisfaction with the policies is related to actor satisfaction with the process $[13,14]$, we investigated both aspects of the governance of climate adaptation.

Actors perceive a shared responsibility with respect to climate adaptation in this unembanked inner-city area development. Therefore, we may expect an adaptive policy network [34] that integrates climate adaptation measures with the other policy aims of this inner-city area development. In addition, stakeholders would be dependent on one another, and through the exchange of resources (money, knowledge, information) they might reach their aims; this also would require a shared vision regarding both the area development and the most effective climate adaptation measures [29].
However, in practice we found traditional hierarchical government steering with respect to water-safety policies, namely elevation of the land as an instrument to increase water safety in the neighborhood. An explanation for this hierarchical government steering can be found in the path-dependency of former Dutch sectoral water management [22]. Within this hierarchical but also neo-liberal governance arrangement, government sets the standards and market parties are responsible for climate adaptation implementation in the neighborhood. Market parties are dissatisfied with this division of responsibility, because only they pay the costs of water safety in the neighborhood [50]. Besides, this hierarchical steering restricts innovation in climate adaptation, whereas the market has a self-steering capacity to be innovative. Therefore, opportunities to increase the adaptive capacity are not taken seriously. Furthermore, uncertainty about future climate change is not taken into account.

This hierarchical steering also makes cooperation difficult, because no attention is paid to the specific context in the area and the actors' interests. But recently, the municipality has taken the first steps in adaptive management by bringing stakeholders together in expert meetings and by sharing information and knowledge [26,28] However, until now residents have been excluded from these meetings, while water-safety policies are directed towards their neighborhood. This can decrease the adaptive capacity in the neighborhood [21].

With respect to support for climate adaptive measures, we conclude that the sectoral adaptive measure of elevation of the land generates important negative effects on other policy aims for the area, such as improving spatial quality and the (social) quality of the living environment. Furthermore, it leads to a division with respect to water safety in the neighborhood, because only rebuilding locations will be elevated. From a social justice perspective, this approach can be questioned with regard to the division of risks [18]: residents in social housing with fewer resources are excluded from water-safety policies, while more affluent households in the new dwellings are included.

In sum, there is not much stakeholder support for this adaptive measure. This also reveals the relation between dissatisfaction with the process and with the policy $[13,14]$. However, until now, market parties' financial considerations have been decisive in choosing this adaptation measure for a redevelopment location. This could have been different, with a combination of adaptive measures and by linking other investments in the area [58], or in other words by an integral approach in urban planning.

Our research also reveals that the support for specific adaptation measures (quay, dry-proof and wet-proof 
buildings) is very context dependent [16,36]. For example, it depends on the spatial design in the neighborhood, the potential flood depth in the area, and decisions about the existing housing stock (demolishing or not/renovation or not). Probably, a combination of adaptive measures could also have increased the feasibility of these alternatives, with specific disadvantages of an adaptive measure being compensated by other adaptive measures. Therefore, stakeholders support the importance of the development of an integral adaptive strategy for the neighborhood.

The main conclusion is that the most important barriers for integrating climate adaptation measures into that neighborhood are policy fragmentation of water-safety policy (elevation of rebuilding locations) and the hierarchical governance arrangement in water management. This type of fragmentation led on in its turn to fragmentation with other policy goals for the neighborhood. This certainly does not contribute to a resilient city [9]. It also led to fragmentation in the same neighborhood between areas that received political attention and those that were excluded from the water-safety policy. This divergence as an effect of policy-making in water safety makes the approach questionable in terms of social justice. Another important side effect is that this governance arrangement also restricts innovation towards climate adaptation.

Therefore, an important lesson learned is that integrating water-safety policies in urban planning (in its capacity as a more integrative and spatial comprehensive approach (see also: [10-12])) should be considered the best option to increase the adaptive capacity in delta cities all over the world, ranging from Bangkok to New Orleans. Not only can the negative effects in terms of policy fragmentation be dealt with effectively, but spatial fragmentation can also be tackled.

\section{REFERENCES}

[1] Planbureau voor de Leefomgeving (PBL) (Netherlands Environmental Assessment Agency), "Een Delta in Beweging. Bouwstenen voor een Klimaatbestendige Ontwikkeling van Nederland,” PBL, Den Haag, 2011.

[2] H. Meyer, A.-L. Nilessen and W. Zonneveld, "Rotterdam: A City and a Mainport on the Edge of a Delta," European Planning Studies, Vol. 20, No. 1, 2012, pp. 71-94. doi:10.1080/09654313.2011.638498

[3] W. N. Adger, et al., "Assessment of Adaptation Practices, Options, Constraints and Capacity. Climate Change 2007: Impacts, Adaptation and Vulnerability. Contribution of Working Group II to the Fourth Assessment Report of the Intergovernmental Panel on Climate Change,” In: M. L. Parry, O. F. Canziani, J. P. Palutikof, P. J. van der Linden and C. E. Hanson, Eds., Cambridge University Press, Cambridge, 2007, pp. 717-743.

[4] N. Brooks, W. N. Adger and P. M. Kelly, "The Determinants of Vulnerability and Adaptive Capacity at the Na- tional Level and Implications for Adaptation,” Global Environmental Change, Vol. 15, No. 2, 2005, pp. 151163. doi:10.1016/j.gloenvcha.2004.12.006

[5] H. Meyer, "Reinventing the Dutch Delta, Complexity and Conflicts,” Built Environment, Vol. 35, No. 4, 2009, pp. 432-451. doi:10.2148/benv.35.4.432

[6] H. Priemus and S. Davoudi, "Introduction to the Special Issue,” European Planning Studies, Vol. 20, No. 1, 2012, pp. 1-6. doi:10.1080/09654313.2011.638495

[7] A. Kokx, "Between Dreams and Reality, Urban Governance in the Process of Dutch Urban Restructuring," Ph.D. Thesis, Nederlandse Geografische Studies 394, Knag/Faculteit Geowetenschappen, Utrecht University, Utrecht, 2010.

[8] J. Evans, "Resilience, Ecology and Adaptation in the Experimental City," Transactions of the Institute of British Geographers, Vol. 36, No. 2, 2011, pp. 223-237. doi:10.1111/j.1475-5661.2010.00420.x

[9] S. Pickett, M. Cadenasso and J. Grove, "Resilient Cities: Meaning, Models, and Metaphor for Integrating the Ecological, Socio-Economic, and Planning Realms," Landscape and Urban Planning, Vol. 69, No. 4, 2004, pp. 369-384. doi:10.1016/j.landurbplan.2003.10.035

[10] H. Blanco, et al., "Hot, Congested, Crowded and Diverse: Emerging Research Agendas in Planning," Progress in Planning, Vol. 71, No. 4, 2009, pp. 153-205. doi:10.1016/j.progress.2009.03.001

[11] W. N. Adger, et al., "Are There Social Limits to Adaptation to Climate Change?” Climate Change, Vol. 93, No. 3, 2009, pp. 335-354. doi:10.1007/s10584-008-9520-z

[12] J. De Boer, “On the Relationship Between Risk Perception and Climate Proofing,” Knowlegde for Climate (KfC) 013, 2010.

[13] J. Edelenbos and E. H. Klijn, "Managing Stakeholder Involvement in Decision-Making: A Comparative Analysis of Six Interactive Processes in The Netherlands," Journal of Public Administration Research and Theory, Vol. 16, No. 3, 2005, pp. 417-446. doi:10.1093/jopart/mui049

[14] M. Boedeltje, "Draagvlak Door Interactief Bestuur: Fictie of Feit?” Ph.D. Thesis, Twente University, Enschede, 2009.

[15] J. Pierre, "Comparative Urban Governance: Uncovering Complex Causalities," Urban Affairs Review, Vol. 40, No. 4, 2005, pp. 446-462. doi:10.1177/1078087404273442

[16] W. N. Adger, N. Arnell and E. Tompkins, "Successful Adaptation to Climate Change Across Scales," Global Environmental Change, Vol. 15, No. 2, 2005, pp. 77-86. doi:10.1016/j.gloenvcha.2004.12.005

[17] H. M. Füssel, "Adaptation Planning for Climate Change: Concepts, Assessment Approaches, and Key Lessons," Sustainability Science, Vol. 2, No. 2, 2007, pp. 265-275.

[18] W. N. Adger, "Climate Change, Human Well-Being and Insecurity,” New Political Economy, Vol. 15, No. 2, 2010, pp. 275-292. doi:10.1080/13563460903290912

[19] C. Jacquier, “On Relationships between Integrated Policies for Sustainable Urban Development and Urban Governance," Tijdschrift voor Economische en Sociale Geo- 
grafie, Vol. 96, No. 4, 2005, pp. 363-367. doi:10.1111/j.1467-9663.2005.00469.x

[20] H. Mees and P. Driessen, "Adaptation to Climate Change in Urban Areas: Climate-Greening London, Rotterdam, and Toronto," Climate Law, Vol. 2, No. 2, 2011, pp. 251280.

[21] A. Kokx and T. Spit, "The Production of Unproductive Policy-Making: Climate Adaptation, EU Projects, Policy Entrepreneurs and Policy Change: the Dutch Experience,” Unpublished.

[22] J. Woltjer and N. Al, "Integrating Water Management and Spatial Planning," Journal of the American Planning Association, Vol. 72, No. 2, 2007, pp. 211-222. doi:10.1080/01944360708976154

[23] Ministerie van Volkshuisvesting, Ruimtelijke Ordening en Milieu (VROM), “Doorwerking van Klimaatadaptatie in Ruimtelijke Plannen. Een Monitoring van de Gemeentelijke Praktijk,” VROM-Inspectie, Ministerie van Ruimtelijke Ordening en Milieubeheer, Den Haag, 2010.

[24] P. P. J. Driessen, et al., "Beleids en Rechtswetenschappelijke Aspecten van Klimaatadaptatie,” Kennis voor Klimaat [KvK], Wageningen, 2011.

[25] T. Spit and P. Zoete, "Ruimtelijke Ordening in Nederland. Een Wetenschappelijke Inleiding in het Vakgebied," Geheel Herziene Editie, Sdu Uitgevers, Den Haag, 2009.

[26] C. Folke, T. Hahn, P. Olson and J. Norberg, "Adaptive Governance of Social-Ecological Systems," Annual Review of Environment and Resources, Vol. 30, 2005, pp. 441-474. doi:10.1146/annurev.energy.30.050504.144511

[27] F. B. Van der Meer and J. Edelenbos, "Evaluation in Multi-Actor Policy Processes, Accountability, Learning and Cooperation,” Evaluation, Vol. 12, No. 2, 2006, pp. 201-218. doi:10.1177/1356389006066972

[28] S. Moser and J. Ekstrom, "A Framework to Diagnose Barriers to Climate Change Adaptation," Proceedings of the National Academy of Sciences USA (PNAS), Vol. 107, No. 51, 2010, pp. 22026-22031. doi:10.1073/pnas.1007887107

[29] R. Rhodes, "The New Governance: Governing without Government,” Political Studies, Vol. 44, No. 4, 1996, pp. 652-667. doi:10.1111/j.1467-9248.1996.tb01747.x

[30] H. Runhaar, P. Driessen and L. Snoer, "Sustainable Urban Development and the Challenge of Policy Integration: an Assessment of Planning Tools for Integrating Spatial and Environmental Planning in The Netherlands," Environment and Planning B: Planning and Design, Vol. 36, No. 3, 2009, pp. 417-431. doi:10.1068/b34052

[31] J. Carter, "Climate Change Adaptation in European Cities,” Environmental Sustainability, Vol. 3, No. 3, 2011, pp. 193-198.

[32] C. Pahl-Wostl, "Transitions towards Adaptive Management of Water Facing Climate and Global Change," Water Resources Management, Vol. 21, No. 1, 2007, pp. 4962. doi:10.1007/s11269-006-9040-4

[33] C. Pahl-Wostl, “A Conceptual Framework for Analysing Adaptive Capacity and Multi-Level Learning Processes in Resource Governance Regimes," Global Environmental Change, Vol. 19, No. 3, 2009, pp. 354-365. doi:10.1016/j.gloenvcha.2009.06.001

[34] G. Teisman, A. Van Buuren and L. Gerrits, "Managing Complex Governance Systems, Dynamics, Self-Organisation and Coevolutions in Public Investments,” Routledge, London, 2009.

[35] M. Mens, F. Klijn, K. De Bruijn and E. Van Beek, “The Meaning of System Robustness of Flood Risk Management," Environmental Science \& Policy, Vol. 14, No. 2, 2011, pp. 1121-1131. doi:10.1016/j.envsci.2011.08.003

[36] D. Nelson, W. Adger and K. Brown, “Adaptation to Environmental Change: Contributions of a Resilience Framework," Annual Review of Environment and Resources, Vol. 32, 2007, pp. 395-419. doi:10.1146/annurev.energy.32.051807.090348

[37] R. Lempert, D. Groves, S. Popper and S. Bankes, “A General, Analytic Method for Generating Robust Strategies and Narrative Scenarios,” Management Science, Vol. 52, No. 4, 2006, pp. 514-528. doi:10.1287/mnsc.1050.0472

[38] S. Dessai and M. Hulme, "Assessing the Robustness of Adaptation Decisions to Climate Change Uncertainties: A Case Study on Water Resources Management in the East of England,” Global Environmental Change, Vol. 17, No. 1, 2007, pp. 59-72. doi:10.1016/j.gloenvcha.2006.11.005

[39] J. Wardekker, A. de Jong, J. Knoop and J. van der Sluijs, "Operationalising a Resilience Approach to Adapting an Urban Delta to Uncertain Climate Changes,” Technological Forecasting and Social Change, Vol. 77, No. 6, 2010, pp. 987-998. doi:10.1016/j.techfore.2009.11.005

[40] I. Lorenzoni, S. Nicholson-Cole and L. Whitmarsh, "Barriers to Engaging with Climate Change among the UK Public and Their Policy Implications,” Global Environmental Change, Vol. 17, No. 3-4, 2007, pp. 445-459. doi:10.1016/j.gloenvcha.2007.01.004

[41] R. Biesbroek, J. Klostermann, C. Termeer and P. Kabat,” Barriers to Climate Change Adaptation in the Netherlands,” Climate Law, Vol. 2, No. 2, 2011, pp. 181-199.

[42] M. Mintrom and P. Norman, "Policy Entrepreneurship and Policy Change,” The Policy Studies Journal, Vol. 37, No. 4, 2009, pp. 649-667. doi:10.1111/j.1541-0072.2009.00329.x

[43] D. Huitema and S. Meierink, "Realizing Water Transitions: The Role of Policy Entrepreneurs in Water Policy Change,” Ecology and Society, Vol. 15, No. 2, Article 26, 2010. http://www.ecologyandsociety.org/vol15/iss2/art26.

[44] J. Kingdon, “Agendas, Alternatives and Public Policies," 2nd Edition, HarperCollins, New York, 1995.

[45] E.-H. Klijn and J. Koppenjan, "Public Management and Policy Networks, Foundations for a Network Approach to Governance,” Public Management, Vol. 2, No. 2, 2000, pp. 135-158. doi:10.1080/146166700411201

[46] J. Davies, "Local Governance and the Dialectics of Hierarchy, Market and Network,” Policy Studies, Vol. 26, No. 3-4, 2005, pp. 311-335. doi:10.1080/01442870500198379

[47] G. Stoker, "Governance as Theory: Five Propositions," International Social Sciences Journal, Vol. 50, No. 155, 1998, pp. 17-28. doi:10.1111/1468-2451.00106

[48] J. March and J. P. Olsen, “Ambiguity and Choice in Or- 
ganizations,” Universitets-Forlaget, Bergen, 1976, pp. 3853.

[49] P. Lascoumes and P. Le Galès, "Introduction: Understanding Public Policy Through Its Instruments-From the Nature of Instruments to the Sociology of Public Policy Instrumentation," Governance: An International Journal of Policy, Administration, and Institutions, Vol. 20, No. 1, 2007, pp. 1-21. doi:10.1111/j.1468-0491.2007.00342.x

[50] C. Clarke, "Dissolving the Public Realm? The Logics and Limits of Neo-Liberalism,” Journal of Social Policy, Vol. 33, No.1, 2004, pp. 27-48. doi:10.1017/S0047279403007244

[51] M. Taylor, "Community Participation in the Real World: Opportunities and Pitfalls in New Governance Spaces,” Urban Studies, Vol. 44, No. 2, 2007, pp. 297-317. doi:10.1080/00420980601074987

[52] D. Huitema, et al., “Adaptive Water Governance: Assessing the Institutional Prescriptions of Adaptive (Co)Management from a Governance Perspective in Defining a Research Agenda," Ecology and Society, Vol. 14, No. 1, Article 26, 2009.

http://www.ecologyandsociety.org/vol14/iss1/art26/

[53] Wetenschappelijke Raad voor het Regeringsbeleid (WRR), "Vertrouwen in de Buurt," WRR, Amsterdam University Press, Amsterdam, 2005.

[54] K. Williams, J. Joynt and D. Hopkins, “Adapting to Climate Change in the Compact City: The Suburban Challenge,” Built Environment, Vol. 36, No. 1, 2010, pp. 105114. doi:10.2148/benv.36.1.105

[55] E. Hamin and N. Gurran, "Urban Form and Climate Change: Balancing Adaptation and Mitigation in the US and Australia," Habitat International, Vol. 33, No. 3, 2009, pp. 238-245. doi:10.1016/j.habitatint.2008.10.005

[56] F. Grazi, J. C. J. M. van den Bergh and J. N. van Ommeren, "An Empirical Analysis of Urban Form, Transport and Global Warming,” The Energy Journal, Vol. 29, No. 4, 2008, pp. 97-122. doi:10.5547/ISSN0195-6574-EJ-Vol29-No4-5

[57] K. Van Nieuwaal, P. P. J. Driessen, T. J. M. Spit and K. Termeer, "A State of the Art of Governance Literature on Adaptation to Climate Change: Towards a Research Agenda," IOP Conference Series: Earth and Environmental Science, Vol. 6, No. 36, 2009, p. 362019.

[58] J. Koppenjan and E.-H. Klijn, "Managing Uncertainties in Networks. A Network Approach to Problem Solving and Decision Making,” Routledge, London, 2004.
[59] S. Hallegatte, F. Henriet and J. Corfee-Morlot, "The Economics of Climate Change. Impacts and Policy Benefits at City Scale: A Conceptual Framework,” Environmental Working Paper, OECD, Paris, 2008.

[60] L. Kamal-Chaoui and A. Robert, "Competitive Cities and Climate Change,” OECD Regional Development Working Papers, OECD, Paris, 2009.

[61] R. Willows and R. Connell, "Climate Adaptation: Risk, Uncertainty and Decision-Making,” UKCIP Technical Report, UKCIP, Oxford, 2003.

[62] S. Dessai and J. Van der Sluis, "Uncertainty and Climate Change. A Scoping Study,” Copernicus Institute, Utrecht University, Utrecht, 2007.

[63] C. Zevenbergen, W. Verbeek, B. Gersonius and S. Van Herk, "Challenges in Urban Flood management: Travelling across Spatial and Temporal Scales,” Flood Risk Management, Vol. 1, No. 2, 2008, pp. 81-88. doi:10.1111/j.1753-318X.2008.00010.X

[64] W. Verbeek, et al., "Flood Risk in Unembanked Areas, Synthesis,” Kennis voor Klimaat, Amsterdam, 2010.

[65] Gemeente Rotterdam, "Masterplan Kop van Feijenoord, Fase II Kop van Zuid,” Stadsontwikkeling, Gemeente Rotterdam, 2011.

[66] Ministerie van Verkeer en Waterstaat (V\&W), Ministerie van Volkshuishuisvesting, Ruimtelijke Ordening en Milieubeheer (VROM) en het Ministerie van Landbouw, Natuur en Voedselkwaliteit (LNV), "Beleidsnota Waterveiligheid 2009-2015,” Ministeries van V\&W, VROM and LNV, Den Haag, 2009.

[67] Ministerie van Verkeer en Waterstaat (V\&W) \& Ministerie van Volkshuishuisvesting, Ruimtelijke Ordening en Milieubeheer (VROM), “Beleidslijn Grote Rivieren,” Ministeries van V\&W and VROM, Den Haag, 2006.

[68] K. Batterbee, et al., "Klaar Voor Hoog Water, Verkennend Onderzoek Naar Adaptieve Strategieën in het Buitendijks Gebied in de Hotspot Rotterdam,” Kennis voor Klimaat 025, 2010.

[69] E. Van Bergeijk, A. Kokx, G. Bolt and R. Van Kempen, "Helpt Herstructurering? Effecten van Stedelijke Herstructurering op Wijken en Bewoners,” Eburon, Delft, 2008.

[70] W. N. Adger, "Social Capital, Collective Action, and Adaptation to Climate Change,” Economic Geography, Vol. 79, No. 4, 2003, pp. 387-404. doi:10.1111/j.1944-8287.2003.tb00220.x 